\title{
Trends in Islamic Studies in the United States and Canada since the 1970s
}

Islamic studies, like women's studies, Afro-American studies, or Judaic studies, is a field defined by subject matter rather than a particular scholarly tradition or disciplinary approach. However, in contrast to most of these other fields, there is scarcely a department of Islamic studies in Canada or the United States. ${ }^{1}$ Most Islamic studies positions are found within departments of religious studies and in area studies centers, although within the latter they are not generally taught by scholars whose training had a major emphasis on studies of the Islamic religion. It is misleading to conclude that the study of Islam takes place solely within Middle East area studies programs, for at this juncture scholarship focusing on Muslims in other parts of $\mathrm{Asia}^{2}{ }^{2}$ on Muslim minorities generally, and on Muslims in North America in particular, is a growing trend. ${ }^{3}$

In terms of scholarly heritage, most of those pursuing Islamic studies face the same concerns felt by the area specialist or the historian of religion. In some respects area studies and religious studies have faced similar challenges. For instance, both foster eclectic theoretical orientations that can result in either creative synthesis or superficial or "trendy" applications of the latest methodologies. Both face common dangers: that the collection and description of data will displace theoretical concerns; the

'The only ones are in Canada: the Institute of Islamic Studies at McGill University (Montreal) and the Middle East and Islamic Studies Department at the University of Toronto. An additional measure of the scope of programs in Islamic studies might be the awarding of the Ph.D. degree in this field, rather than as a subcategory of Near Eastern studies. In that case we may add, for example, the University of California, Los Angeles.

${ }^{2}$ The inclusion of more material on Muslims in south and southeast Asia in surveys of Islam is becoming a more consistent aspect of recent scholarship. Examples are Francis Robinson's Atlas of the Islamic World Since 1500 (New York: Facts on File, 1982), John Voll's Islam: Continuity and Change in the Modern World (Boulder, CO: Westview, 1982), and Frederick M. Denny's textbook An Introduction to Islam (New York: Macmillan, 1985). Mark Woodward's Islam in Java: Normative Piety and Mysticism in the Sultanate of Yogyakarta (Tucson: University of Arizona, 1989) is an example of history of religions scholarship focusing on Islam in southeast Asia.

${ }^{3}$ Examples are Earle H. Waugh, Regula B. Qureshi, and Baha Abu-Laban, eds., The Muslim Community in North America (Edmonton: University of Alberta, 1983); Earle H. Waugh et. al., eds., Muslim Families in North America (Edmonton: University of Alberta, 1991) and the studies on Muslims in North America undertaken by Yvonne Y. Haddad, Muslim Values in North America (New York: Oxford, 1987) and Muslims of America (New York: Oxford, 1991). For bibliographies, see Yvonne Y. Haddad, "Muslims in America: A Select Bibliography," Muslim World 76 (2 April 1986): 93-122 and her two more recent publications.

The Muslim community in North America is also interacting more frequently with the academic establishment. For example, a number of local imams, initially trained abroad, are pursuing advanced degrees in Islamic studies at North American universities. 
problems of ethnocentrism; the need to bridge the gap between the experience and perceptions of the insider and the outsider (the observed and the observer); and extensive linguistic and cultural preparation in addition to theoretical or disciplinary training.

The situation is rendered more complex due to the fact that scholars working within the broadly defined scope of Islamic studies may come from at least five disparate academic backgrounds. These are: area studies programs, graduate departments of religious studies, a particular social science, a humanities field, or even a traditional Islamic education followed by a period of training in a Western academic institution. Scholars from any one of these backgrounds may focus their work to a greater or lesser extent on the study of the Islamic religious tradition.

In terms of the institutionalization of scholarship, a recent graduate defined primarily as an Islamicist must have developed a secondary field, disciplinary training, or skill in order to be employable in today's academic marketplace. Such secondary fields are primarily religious studies, language and literature, or history. There is no professional forum focused uniquely on the scholarly study of the Islamic religious tradition. While panels focused on an aspect of Islam might be mounted at any number of professional associations, the most likely forum for those scholars of Islam who are primarily interested in religion is the revitalized section on Islamics at the American Academy of Religion. Somewhat broader disciplinary gatherings are the Association for the Study of Middle Eastern and South Asian Muslim Societies, held at Villanova University every spring, and the Association of Muslim Social Scientists, which concentrates on the theme of Islamic thought in relationship to the humanities and the social sciences.

Islam has long been neglected within religious studies both in terms of being a topic for scholarly research and in terms of allotment of academic positions. While the situation has improved over the past ten years, the general slowing down of growth in the humanities has limited the number of new positions that could be allotted to Islamicists as well as to scholars of other religious traditions. At one point, interest in Islam generally, together with the fact that it had been neglected for so long in departments of religion, gave junior Islamicists hope that a spate of new positions would be forthcoming. This, in fact, does not seem to have been the case, although junior scholars of the Islamic religion are still probably in a better academic employment position than, say, students of Islamic history or Hinduism.

A positive development, which has occurred over the past decade or so, is the greater integration of Islamic studies into the wider history of religions community, both institutionally and theoretically. In an article published in the 1960s, Charles J. Adams concluded that "it is difficult to see a direct and fructifying relationship between the activities of the 
Islamicist and those of historians of religions. ${ }^{4}$ But by the early 1980 s, a prominent historian of religion was pleased to cite a growing number of scholars trained in Islamics with a strong religious studies background whose work evidenced just this sort of mutually productive dialogue between fields. ${ }^{5}$ This, together with the recent concern of the American Academy of Religion over revitalizing and supporting its Islamicist contingent, are indications of a coming of age of Islamic studies within the field of religious studies.

In surveying the publications related to this field since Adams' comprehensive review articles of the mid-1970s, ${ }^{6}$ the most striking trend emerging could be subsumed under sensitivity to indigenous categories and concepts as part of an increased concern with methodologies and their wider implications. Contributing in no small part to this awareness are the ongoing methodological and disciplinary debates within both area studies and religious studies. Islamicists are now engaging in scholarship that incorporates this new reflectiveness and methodological sophistication. A summary of such efforts from the point of view of religious studies is the collection of articles in Martin's (ed.) Approaches to Islam in Religious Studies (1985). The reader is referred to the introductory chapter on "Islamic Studies within Scholarship in the History of Religions" for a review of the development of methodological concerns within each field.

Recent publications indicate that the way Islam is understood by scholars is undergoing a change due to increased attention paid to the shaping function of imposed definitions and concepts. A major contribu-

${ }^{4}$ Charles J. Adams, "The History of Religions and the Study of Islam," in The History of Religions: Essays on the Problem of Understanding, ed. Joseph M. Kitagawa with Mircea Eliade and Charles H. Long (Chicago and London: University of Chicago Press, 1967), 177-93. Cited in R. C. Martin, Approaches to Islam in Religious Studies (Tempe: University of Arizona, 1985), 3.

${ }^{5}$ Frank Reynolds, "History of Religions: Condition and Prospects," Bulletin for the Council of the Study of Religion (December 1982): 131-3. Islamicists were thus rather surprised when Arthur W. Shippee recently stated that "the efforts of historians of religions have yielded little to the study of Islam" in Humanities Magazine (May/June 1990): 30. While exception may be taken to a number of Shippee's characterizations of the Islamic tradition, such as "Islam was born and matured in the full light of history on an isolated island of sand," his position that "the study of Islam may provoke historians of religion to revise some of their categories" is well taken.

6"Islam," in A Reader's Guide to the Great Religions, ed. C. J. Adams, 2d ed. (New York: Macmillan, 1977), 407-66; "Islamic Religious Tradition," in The Study of the Middle East: Research and Scholarship in the Humanities and Social Sciences, ed. Leonard Binder (New York: Wiley, 1976), 29-95. Islamic Studies: A Tradition and Its Problems was the title of a Della Vida Conference volume edited by Malcolm $\mathrm{H}$. Kerr (Malibu: Undena Publications, 1985). A more recent overview of the field is Jacques Waardenberg, "Islamic Studies," in Encyclopedia of Religion, ed. M. Eliade, vol. 7, 45764. For comments on the articles in Islamic studies included in the Encyclopedia of Religion, see Jane McAuliffe, "Moments of Delight and Disappointment," in Critical Review of Books in Religion (Atlanta: Scholars Press, 1989), 57-76. 
tion to this increased sensitivity to terminology has been the long-term concern of Wilfred Cantwell Smith with exposing the distortion that arises due to understanding religion in an essentialist ahistorical way. ${ }^{7}$ The impact of his "personalist" approach to religious meaning meshes with today's increased exposure to living Muslim cultures on the part of both social scientists and textually oriented scholars of the humanities. $\mathrm{He}$ leads us to reflect on the most basic concepts, even the term "Islam. ${ }^{18}$ For Smith, the scholarly object is the faith held by the Muslim individual and its expression as evolving tradition rather than a fixed norm that must be discovered. In addition, the test of a true statement about Islam or any other faith is whether an insider would assent to it.

Not all may agree with the critique of methodology and the challenge to concepts of normativity held by both insiders and scholars adhering to this view. However, the implication that the tradition's own concepts and categories need to be understood as evolving in process has led to the reconsideration of fundamental assumptions about the meaning of such basic terms as "Islam" or "Shari"ah." By counting the frequency of appearance of such key terms in works produced throughout the historical development of a tradition, Smith points out the misleading tendency to fix on a current, ahistorical understanding of such terms and then read them back as being of constant importance and meaning throughout the evolution of a religion.

A similarly influential revision of some basic terminology in the field from the historian's perspective was undertaken by Marshall Hodgson in The Venture of Islam (1974). The introduction to this work, which distinguishes "Islamic" from "Islamicate," ${ }^{10}$ has influenced a more careful use of nomenclature and periodization in relationship to the Islamic tradition by scholars of religion and historians. On the basis of this distinction, one can question whether Islamic studies is a misleading designation for the field. Hodgson suggests "Islamics studies" (of the religion) and its differentiation from "Islamdom studies (of the civilization)." ${ }^{11}$

Said's exposé of Orientalism (1978) may have had a dramatic effect in making scholars aware of the political agendas supporting the portrayal

${ }^{7}$ Wilfred Cantwell Smith, The Meaning and End of Religion (New York: Macmillan, 1963), chapter 4 .

${ }^{8} \mathrm{As}$ in "The Historical Development in Islam of the Concept of Islam as an Historical Development," in On Understanding Islam, ed. Wilfred C. Smith (The Hague: Mouton, 1981), 41-77.

${ }^{9}$ As in "Islamic Law: Shariah and Shar"" (reprinted) in On Understanding Islam, ed. Wilfred C. Smith (The Hague: Mouton, 1981), pp. 87-109.

${ }^{10}$ Marshall S. Hodgson, The Venture of Islam, vol. 1 (Chicago: University of Chicago Press, 1974), 57-60.

${ }^{11}$ Ibid., 41, 56. 
of Muslim thought and society as "other." However, a more gradual sensitizing impact has been made by the widespread acceptance of a phenomenological attitude to appreciating the insiders' cultural and intellectual world as reflected in institutions, texts, rituals, other cultural productions, and all aspects of social interaction. The accusation of being an orientalist-beyond critiquing an implicit or explicit political stance-has become within the field a critique of the limitations of the strictly philological, descriptive, or tracing the history-of-an-idea approach. The strategies for situating a translation, whether of a text or a cultural production, in a thicker interpretive context may now incorporate multidisciplinary or cross-disciplinary methods of interpretation such as structural analysis, narrative theory, phenomenology, semiotics, discourse theory, and ethnomethodology. While this growing trend is evident in the field, there remains a tension between the respect for the tradition of solid textual scholarship and the attraction of the exciting, novel, but potentially transitory contributions of showing that an approach that proved illuminating or powerfully explanatory elsewhere can be innovatively applied to this field. ${ }^{12}$

The flourishing of such language training and fellowship programs as the Foreign Area Fellowship Program, CASA (Center for Arabic Studies Abroad), NDFL Title VI Language Fellowships, Social Science Research Council, Fulbright awards, the American Research Center in Cairo, the American Research Institute in Turkey, and the Berkeley Urdu Program, should be acknowledged in affording American scholars unparalleled opportunities to acquire advanced foreign language skills and first-hand knowledge of Islamic societies. It is therefore surprising how little philological, editing, and translation work is being done despite generous grant support. One factor is the lack of recognition given to such scholarship by promotion committees in comparison to more analytic types of scholarship. Another is the difficulty of retaining very advanced levels of foreign language skills, particularly in the case of Arabic. Fortunately, this need has begun to be met by faculty language reimmersion programs such as CASA III in Cairo and the new Arabic Speaking Immersion Program at the University of Jordan, Amman.

A recent trend is an interest in fostering more direct contact and scholarly communication among North American scholars and their counterparts in Muslim societies. While this occurs on the individual level, there is still a remarkable degree of isolation and lack of cooperative ef-

${ }^{12}$ While Akbar Ahmed cites a handful of Western scholars as exemplifying a "postorientalistic" trend in his Postmodernism and Islam (London: Routledge, 1992), 184, this paper argues that the trend is much broader. A recent tendency of appointing social scientists not particularly grounded in the religious tradition to positions in Islamic studies within religion departments at American universities may reflect this trend. However it more likely indicates a subtle "neo-orientalistic" agenda of discomfort at having Islam taught on equal footing with other traditions as a religious system. This is balanced by the increasing number of younger American Muslim and immigrant scholars who are finding positions and peer acceptance in the academy. 
fort. The Social Science Research Council has done some work in this field, and it seems that the Fulbright and other American programs may also attempt to initiate further networking and communication at the international level. The American Academy of Religion, for example, seeks to increase the level of international scholarly participation across all sections, including Islamics.

Overall, the current model for the ideal Islamicist combines solid training in the languages, texts, and history of the field with the methodological sophistication and originality to explain or interpret the subject in a significant way. A review of recent scholarship indicates that the preferred "new methods" among Islamicists are adapted, for the most part, from the history of religions and the humanities rather than from the social science disciplines. At the same time, it should be noted that even those social scientists who have developed rigorous language and textual studies backgrounds tend to be identified in terms of their theoretical discipline. Characteristically, their approach to the data, whether textual or observed, will be explanatory. However, with current historical and anthropological methodologies in particular, an affinity to a more phenomenological attitude, consonant with the concerns of the history of religions, may be observed.

Due in part to the area studies framework, which has encouraged the interaction of scholars across disciplinary lines, and to the renewed interest of social scientists in the persistence and cogency of religions, most notably Islam, as a theoretically important research topic, we presently have more dialogue between Islamicists and social scientists. In some areas, there is even a blurring of the distinctions between the two. As a result, Islamicists have become more aware of non-normative "little tradition" manifestations of the Islamic heritage in local contexts. An issue raised by this trend is whether the social science approach to "recognizing" Islam challenges the concept of unity and normativity within Islam. The poles of this debate can be recognized in a number of scholarly exchanges. One example is the late Fazlur Rahman's critique of the emphasis of some anthropologists and sociologists on the "little tradition" or "Islam as it is actually lived understood as a static norm in its own terms, thus constituting a notion of multiple Islams and ultimately no Islam." ${ }^{13}$ A closer examination of the authority of normative Islam points out issues congruent with those raised by Smith's "personalist" ${ }^{14}$

${ }^{13}$ Fazlur Rahman, "Approaches to Islam in Religious Studies: Review Essay," in R. C. Martin, Approaches to Islam, 196. For the other side, see Michael Gilsenan, Recognizing Islam (London: Croom Helm, 1982).

${ }^{14}$ Critiqued in turn by I. R. Fārūqī, "The Essence of Religious Experience in Islam," Numen 20 (1973): 186-201. For another dimension of this discussion, see the articles of Islamic art historian Oleg Grabar, for example, "The Study of Islamic Art," Muqärnas 1 (1983): 1-14, and "Geometry and Ideology: The Festival of Islam and the Study of Islamic Art,"in A Way Prepared: Studies in Honor of Richard Bayly Winder, ed. Farhad Kazamy and R. D. McChesney (Albany: SUNY Press, 1988), 145-52. 
approach within religious studies and Hodgson's discussion of "the Islamic vision in religion and in civilization." ${ }^{15}$

The outcome of this awareness of a need to bridge the gap between the ideal or classical model and the experience of individuals in history seems to manifest itself in a number of recent works on Islam that move between the normative, classical textual high tradition and personal selfstatements, interpretations, or observations. One example is Jane I. Smith and Yvonne Y. Haddad's Islamic Understanding of Death and Resurrection (1981). This book is structured to present the Qur'anic view of the topic, classical interpretations, and, finally, contemporary discussions demonstrating developments over time. One issue representing the last category, and reflecting a recent sensitivity, is a woman's place in the afterlife. Other examples are the anthology edited by John L. Esposito and John J. Donahue, Islam in Transition: Muslim Perspectives (1982) and Esposito's Voices of Resurgent Islam (1983). In the latter volume, we have a number of scholarly articles on prominent concepts or individuals within the Islamic reform movements of this century followed by a selection of Muslim self-statements. While a useful didactic purpose is fulfilled by such an arrangement, a certain stance is also implied in allowing the self-statement material to speak "for itself" free of secondary interpretation.

The movement of ethnomethodology, or emic analysis of indigenous concepts within cultural anthropology, has resulted in works by social scientists doing research in specific cultural settings that are increasingly cognizant of normative Islamic categories. These works, by incorporating references to classical great tradition Islam, are more accessible to Islamicists and influence their understanding of textual and nontextual materials and methodologies for their interpretation. ${ }^{16}$

An earlier case in point was Geertz's work on Islamic societies, Islam Observed: Religious Developments in Morocco and Indonesia (1964). This book is used as a textbook in some religion courses due to its clarity and elegant formulation of such central themes as variations in modes of religious expression, i.e., Islam in the different cultural contexts of Indonesia and Morocco, and normative Islam vs. its "little tradition" manifestations. Its description and explanation of common historical tendencies

${ }^{15}$ Hodgson, The Venture of Islam, vol. 1, 71-95.

${ }^{16}$ For an extensive survey of anthropological studies of the Middle East, see Dale Eickelman, The Middle East: An Anthropological Approach (New Jersey: Prentice Hall, 1983). The expansion of the subfield of psychological anthropology has also produced some recent works bearing on Islam. Of particular interest are L. Carl Brown and Norman Itzkowitz's (eds.) Psychological Dimensions of Near Eastern Studies, (Princeton: Darwin Press, 1977), Vincent Crapanzano's books Hamadsha (Berkeley: University of California Press, 1973) and Tuhaimi: Portrait of a Moroccan (Chicago: University of Chicago Press, 1980), which use psychoanalytic methods and interpretations, and James L. Peacock's Muslim Puritans (Berkeley: University of California Press, 1978) which tests both Freud's and Weber's theories on data relevant to Muslims in Indonesia and Malaysia. 
across these cultures remains influential. More recently, Barbara Metcalf's (ed.) Moral Conduct and Authority: The Place of Adab in South Asian Islam (1984) and its sequel, Katherine P. Ewing's (ed.) Shariat and Ambiguity (1988), feature articles by historians, anthropologists, and scholars of the religious tradition who focus on a common theme to portray manifestations of religious and cultural norms.

The conceptual and interpretive challenges faced when studying a tradition with its own worldview and set of terms and categories that explicitly or implicitly order reality involves the contemporary scholar of the Islamic tradition in a dialogue with a range of other disciplines facing similar concerns. At present Islamicists, rather than perceiving their role as being limited to providing raw data through translations and laying philological or history-of-ideas foundations, are beginning to experiment with new cross-disciplinary methodologies. In this process, constructs and methods generated outside of their field are applied to elucidate their own data and ultimately, one hopes, will serve to revise theories or methods that prove to be culture-bound. A case in point is the application of literary or formalist analysis techniques to Qur'anic materials or the genres of Islamic historical and biographical texts. Pioneering work in this latter area has been done by Marilyn R. Waldman ${ }^{17}$ in historical and Qur'anic narrative and by Fedwa Malti-Douglas on biographical dictionaries. ${ }^{18} \mathrm{As}$ part of this trend, a series of panels on several new approaches to Islamic historical literature was mounted at a succession of Middle East Studies Association (MESA) conferences in the late 1970s and early 1980s.

In a number of recent works, the Foucaldian ${ }^{19}$ approach to discourse analysis-revealing the shaping forces of power relations in a society on its intellectual formulations-has been applied with a varying degree of success to Islamic materials. Examples include Said's Orientalism (1978), Fatna Sabbah's Women in the Muslim Unconscious (1984) and Aziz al-Azmeh's recent Arabic Thought and Islamic Societies (1986).

More recently, postmodernism has been directly invoked as an interpretive context by Akbar Ahmed's Postmodernism and Islam (1992), Ernest Gellner's Postmodernism, Reason, and Religion (1992), and Michael Fischer and Mehdi Abedi's Debating Muslims (1990).

Recent scholarship has gone further in allowing Western scholarship to explore the intellectual formation of the Islamic tradition without necessarily internalizing its categories or projecting external ones upon it.

\footnotetext{
${ }^{17}$ Marilyn R. Waldman, Towards a Theory of Historical Narrative (Columbus, OH: Ohio State University Press, 1980).

${ }^{18}$ Fedwa Malti-Douglas, "Dreams, The Blind, and the Semiotics of the Biographical Notices," Studia Islamica 51 (1980): 137-62.

${ }^{19}$ That is, strategies for analyzing the structure of power in a society that are supported by the discursive formulations of textual authority and intellectual argument as suggested by the seminal work of Michel Foucault.
} 
Here I could cite the focus of several scholars on the role of the ulema as bearers of cultural and traditional knowledge and the institutionalization of learning in Islam. The collaboration of a social scientist (Leonard Binder) with an Islamicist (Fazlur Rahman) in this area led to the Islam and Social Change Project at the University of Chicago in the 1970s. Several studies on particular institutions emerged from this project: Qum in Michael Fischer's Iran: From Religious Dispute to Revolution (1980), Al-Azhar in Chris Eccle's Egypt, Islam and Social Change (1983), as well as Fazlur Rahman's Islam and Modernity: The Transformation of an Intellectual Tradition (1982). In addition, Roy Mottahedeh's The Mantle of the Prophet (1985), represents an attempt to get inside the intellectual world of an Iranian scholar trained in the madrasah system, as exemplifying the possibility for scholars of Islam to enter an insider's experience of the tradition. Also noteworthy is Mottahedeh's use of an individual life experience through imaginative biography to illustrate broader religious and cultural themes.

Studies in the role of learned and revered persons in the Islamic tradition recognize the role of these bearers of the religion and parallel the development of a cross-disciplinary interest in this topic. Such studies may examine scholarly networks and their sociocultural impact or may try to formulate more clearly a typology of individuals according to the implicit or explicit roles sanctioned within the culture. As part of this process, employing terms such as "holy" or "saint" to translate the parallel Islamic concepts has come under closer scrutiny arising from a more precise understanding of the Islamic context. ${ }^{20}$ Such studies of the intellectual tradition in Islam have engaged anthropologists, sociologists, historians, and Islamicists. One study of this type by a sociologist is David Lelyveld's Aligarh's First Generation (1978), which focuses on the sociocultural world that shaped the nineteenth-century reformer Sir Sayyid Ahmad Khan as an exemplar of sharif or noble culture and its consequences for Aligarh University's institutionalization. Another example is Richard Eaton's Sufis of Bijapur (1978), which uses textual data from local histories and biographical dictionaries to formulate a typology of Sufi roles in the medieval Deccan.

The interaction between the normative religious and cultural model and the individual life in history as exemplifying or embodying it can be studied effectively through biography. The sociological and anthropological concept of "role model" or "root paradigm" informs our understanding of the shaping of biographical elements in conformity with cultural and religious norms, models, and expectations. ${ }^{21}$ The applicability

${ }^{20}$ Bryan S. Turner, Weber and Islam (London: Croom Helm, 1974), 56-71.

${ }^{21}$ This is the theme of an influential volume of scholarship in the history of religions. It features articles demonstrating a "biographical process" in numerous religious traditions. Donald Capps and Frank Reynolds, eds. The Biographical Process (The Hague: Mouton, 1976). 
of this process to Islamic materials is particularly evident due to the exemplary and stereotypical nature of much classical historical writing. Sacred biography is an expanding research topic within Islamic studies. This is particularly so in Shi'a studies, where Ali Shari'ati's reworking of the lives of Fātimah, Husayn, Abū Dharr and 'Alī have reawakened interest in the exemplary and didactic function of this genre. It is noteworthy that many of the works mentioned elsewhere in this article involve the study of biographical materials. ${ }^{22}$

New approaches have also been used to explode stereotypes about the eighteenth century as a period of Islamic stagnation before the colonial period stimulated a response. Historians such as John Voll ${ }^{23}$ and Peter $\mathrm{Gran}^{24}$ have demonstrated the utility of ingenious readings of traditional sources such as chains of authority (isnäds) and theological texts in order to trace wider intellectual trends and scholarly networks. Further creativity appears in the new uses of Islamic biographical compendia by extracting statistical, cumulative data bases on which to base a broader understanding of the political and theological conflicts in the society based on geographical and class origins. Examples are Carl Petry's The Civilian Elite of Cairo in the Later Middle Ages (1981), Richard C. Bulliet's The Patricians of Nishapur (1972), and Conversion to Islam in the Medieval Period (1979).

In the next section of this article, let me briefly return to some of the traditional subfields within Islamic studies in order to cite some of the works that have been notable in advancing the field over the past decade or so.

Studies of the Qur'an and its interpretation have been one of the most academically vibrant areas of Islamic studies in recent times. New accesses and approaches to the text have now become available. For nonArabists, the first major English Concordance to the Qur'an, compiled by Hanna Kassis (1983), provides an indispensable tool and entry into the semantic structure of the text and its fundamental concepts. Kassis faces the problem of inducting the English reader by starting with a glossary of English concepts and then referring them to a number of apposite Arabic roots. Once a root is located, it can be found listed sequentially, in English alphabetical order, together with all other terms derived from the same root referred to and the verses in which they appear.

One hopes that the development of increasingly sophisticated and user-friendly data bases of Qur'anic and hadith materials will lead to advances in accuracy and interpretation in the relevant fields. The explo-

${ }^{22}$ These developments are reviewed in M. K. Hermansen, "Inter-disciplinary Approaches to Islamic Biographical Literature," Religion 47, no. 1 (January 1988): 163-82.

${ }^{23}$ John Voll, Islam: Continuity and Change (Boulder, CO: Westview, 1982).

${ }^{24}$ Peter Gran, The Islamic Roots of Capitalism: Egypt 1760-1840 (Austin: University of Texas Press, 1979). 
sion of electronic networks and bulletin boards has not really borne fruit yet, but has great potential in an international field such as Islamic studies.

New ground has been broken in Qur'anic studies subsequent to rapid advances in literary theory: i.e., narrative theory, and structural, semiotic, and genre analysis. These are making slow inroads among scholars in the field and can be put to either hermeneutic or historical use. The potential of such new methodologies as hermeneutics and speech-act theory for illuminating the effect of the text has been suggested by Richard C. Martin in several articles. ${ }^{25}$ It has also been exemplified in Marilyn R. Waldman's study of Sūrah Yūsuf, in which she derives elements of a paradigmatic Qur'anic narrative of the prophetic career. ${ }^{26}$ The hermeneutic approach, which no longer aims at reconstruct-ing an Ur-text, discover the author's "intent," or trace outside historical influence, may open up new vistas in understanding how the Qur'an conveys its meaning.

John Wansborough's Quranic Studies (1977) provoked intellectual controversy when it first appeared. However, this was due more to its revisionist historical hypothesis that the Qur'an is a later production (taken to the extreme in Michael Cook's and Patricia Crone's Hagarism [1977]) and its classification of narrative styles of Qur'anic exegesis on the basis of Judaic prototypes, than for its analysis of topoi (themes) and narrative styles in interpretive literature. These areas merit further attention. ${ }^{27}$

Another important trend, begun by Smith, ${ }^{28}$ is interest in the Qur'an as scripture. Interest in the role of scripture among historians of religion was stimulated by Smith's insights, and this has led to an increasing number of publications, many having chapters on the Qur'an. ${ }^{29}$ Another Is-

${ }^{25}$ See his "Understanding the Qur'an in Text and Context," History of Religions 21 (1981-82): 361-84; "Structural Analysis and the Qur'an: Newer Approaches to the Study of Islamic Texts," Journal of the American Academy of Religion: Thematic Studies 47, no. 45 (December 1979): 665-83; and "Islamic Textuality in the Light of Poststructuralist Criticism," in A Way Prepared: Essays of Islamic Culture in Honor of Richard Bayly Winder. eds. Farhad Kazamy and R. D. McChesney (New York: SUNY Press, 1988), 116-31.

${ }^{26}$ See her "New Approaches to Biblical Materials in the Qur'an," Muslim World 75, no. 1 (1985): 1-16.

${ }^{27}$ Two articles reviewing Qur'anic studies and their methodology from differing perspectives are Fazlur Rahman, "Some Recent Books on the Qur'an by Western Authors," in The Journal of Religion 64, no. 1 (1984): 73-95 and Andrew Rippin, "The Qur'an as Literature: Perils, Pitfalls, and Prospects," British Society for Middle East Studies Bulletin 10 (1983): 37-47.

${ }^{28}$ For example, Wilfred C. Smith, "On the True Meaning of Scripture," International Journal of Middle East Studies 11 (1980): 487-505.

${ }^{29}$ See Harold Coward, Sacred Word and Sacred Text: Scripture in World Religions. (New York: Maryknoll Press, 1988); Frederick M. Denny and Rodney L. Taylor, eds. The Holy Book in Comparative Perspective (Columbia: University of South Carolina, 1985); and Denny's "Islam" in Rethinking Scripture. ed. Miriam Levering, (Albany: SUNY Press, 1989). 
lamicist who has moved from the distinctive features of the Qur'anic scripture to consider the role of scripture comparatively is William Graham, whose "Qur'an as Spoken Word: An Islamic Contribution to the Understanding of Scripture," discusses the Qur'an as "the most vivid and convincing example of the active, oral-aural function of the holy writ in the life of a religious community and culture. ${ }^{130}$ Graham continues and expands these insights in comparative perspective in his Beyond the Written Word: Oral Aspects of Scripture in the History of Religions (1987). Aspects of the functions of the Qur'an within the Muslim community (i.e., its recitation and formal and ritual use) have also attracted greater scholarly interest of late. ${ }^{31}$

Indicative of interest in Qur'anic studies among scholars of religion is that the American Academy of Religion devoted a special number of its journal to this field ${ }^{32}$ and regularly includes a section on this topic on its annual conference program.

Interpretation of the Qur'an (tafsir) is also an expanding field. In a sense, any scholarship on the Qur'an adds to the body of tafsir, whether it explicitly refers to the classical exegetical tradition or not, and scholarship on the commentaries reaches back to encompass the text. Among the original English-language tafsirs of this period, we may point to Fazlur Rahman's Major Themes of the Qur'an (1980), which is not only a statement of the author's ethical reading of the text but one of the few thematic expositions of its worldview.

In tafsir studies, the need for a historical overview of Islamic exegesis is a desiderata of the field, ${ }^{33}$ and numerous scholars are working towards this goal. At the time of A. T. Welch's translation of Helmut Gatje's The Qur'an and Its Exegesis (1976), very few translated materials existed in this area. Now the first two volumes of Mahmoud Ayoub's serial translation of excerpts from a range of classical and sectarian commentaries, The Qur'an and Its Interpreters, volumes 1 and 2 (1984,

\footnotetext{
${ }^{30}$ In Richard C. Martin, Approaches to Islam, 29.
}

${ }^{31}$ For example Kristina Nelson, The Art of Reciting the Qur'an (Austin: University of Texas Press, 1985); Said al-Labib, The Recited Qur'an, trans. Bernard Weiss et al. (Princeton: The Darwin Press, 1975); Frederick M. Denny, "Exegesis and Recitation: Their Development as Classical Forms of Qur'anic Piety," in Transitions and Transformations in the History of Religions, eds. Frank E. Reynolds and Theodore M. Ludwig (Leiden: E. J. Brill, 1980), 91-123; "The Adab of Qur'an Recitation: Text and Context," in International Congress for the Study of the Qur'an, ed. A. H. Johns (Canberra: Australian National University, 1980), 143-160.

${ }^{32}$ Journal of the American Academy of Religion, Thematic Studies 47, no. 45 (December 1979).

${ }^{33}$ For a detailed discussion, see Andrew Rippin "The Present Status of Tafsir Studies," Muslim World 72, nos. 3-4 (July-October 1982): 224-238. The state of the art in tafsir studies is represented in the published proceedings of a 1985 tafsir conference held at the University of Calgary: Andrew Rippin, ed., Approaches to the History of the Interpretation of the Qur'an (Oxford: Oxford University Press, 1988). 
1992) provides access in English to basic trends in this field. Thematic or terminological approaches to exegetical literature represent another trend relevant to the history of religions methodology. ${ }^{34}$ It seems likely that once the broad outlines of this field become clearer, analytic and literary approaches both for hermeneutic and historical purposes will play a more significant role. Translations of major tafsir works by single authors will provide an increased sense of this discipline. The first volume of al Tabarī's tafsir is now available in English (1987), ${ }^{35}$ and al Tabataba'i's twenty-volume al Miz̄an is being translated by a team of scholars.

The figure of the Prophet, from a history of religions perspective, has received some recent attention, most notably in Annemarie Schimmel's study ${ }^{36}$ of the readings of the Prophet's sacred biography down through the centuries and across religious orientations among Muslims. Earle H. Waugh has also explored the paradigmatic nature of the understanding of the Prophet in Sufi and popular piety. ${ }^{37}$ A noteworthy contribution to our understanding of the development of early sirah literature is Gordon Newby's The Making of the Last Prophet: A Reconstruction of the Earliest Biography of Muhammad (1989).

Studies of the hadith literature have been somewhat neglected as a field for theoretical research save for William A. Graham's Divine Word and Prophetic Word in Early Islam (1977). He considers the hadith $q u d s i$ (divine sayings) as a means to understanding the formation of divine and prophetic authority concepts in the early period of Islam. Muhammad Muhsin Khan has provided a nine-volume English translation of Sahih al Bukhäri (1979), and other Muslim scholars have published studies of traditional hadith methodology. While thematic approaches to hadith have focused on such topics as their portrayal of

${ }^{34}$ For example, Mahmoud Ayoub's articles "Towards an Islamic Christology," parts 1 \& 2, Muslim World 46, no. 3(1976): 163-88 and 80 (1980): 91-121; Jane McAuliffe's articles such as "Persian Exegetical Evaluation of the Ahl al-Kitab," Muslim World 73, no. 2 (April 1983): 87-105 and her recent Qur'anic Christians: An Analysis of Classical and Modern Exegesis (Cambridge: Cambridge University Press, 1991); also Jane I. Smith, An Historical and Semantic Study of the Term 'Islam' as Seen in a Sequence of Quran Commentaries (Missoula: Scholars Press, 1975).

${ }^{35}$ As is the translation of al Tabarì's thirty-eight volume world history (Albany: SUNY: 1984) undertaken by a team of prominent scholars, each of whom is responsible for one volume.

\footnotetext{
${ }^{36}$ Annemarie Schimmel, And Muhammad is His Messenger: The Veneration of the Prophet in Islamic Piety (Chapel Hill: University of North Carolina Press, 1985).

${ }^{37}$ Earle H. Waugh, "Following the Beloved: Muhammad as Model in the Sufi Tradition," in The Biographical Process, ed. D. Capps and Frank Reynolds (The Hague: Mouton 1976), 63-85, and Richard C. Martin, ed., "The Popular Muhammad," in Approaches to Islam in the History of Religions (Tempe: University of Arizona Press, 1985), 41-61.
} 
lamicist who has moved from the distinctive features of the Qur'anic scripture to consider the role of scripture comparatively is William Graham, whose "Qur'an as Spoken Word: An Islamic Contribution to the Understanding of Scripture," discusses the Qur'an as "the most vivid and convincing example of the active, oral-aural function of the holy writ in the life of a religious community and culture. ${ }^{130}$ Graham continues and expands these insights in comparative perspective in his Beyond the Written Word: Oral Aspects of Scripture in the History of Religions (1987). Aspects of the functions of the Qur'an within the Muslim community (i.e., its recitation and formal and ritual use) have also attracted greater scholarly interest of late. ${ }^{31}$

Indicative of interest in Qur'anic studies among scholars of religion is that the American Academy of Religion devoted a special number of its journal to this field ${ }^{32}$ and regularly includes a section on this topic on its annual conference program.

Interpretation of the Qur'an (tafsir) is also an expanding field. In a sense, any scholarship on the Qur'an adds to the body of tafsir, whether it explicitly refers to the classical exegetical tradition or not, and scholarship on the commentaries reaches back to encompass the text. Among the original English-language tafsirs of this period, we may point to Fazlur Rahman's Major Themes of the Qur'an (1980), which is not only a statement of the author's ethical reading of the text but one of the few thematic expositions of its worldview.

In tafsir studies, the need for a historical overview of Islamic exegesis is a desiderata of the field, ${ }^{33}$ and numerous scholars are working towards this goal. At the time of A. T. Welch's translation of Helmut Gatje's The Qur'an and Its Exegesis (1976), very few translated materials existed in this area. Now the first two volumes of Mahmoud Ayoub's serial translation of excerpts from a range of classical and sectarian commentaries, The Qur'an and Its Interpreters, volumes 1 and 2 (1984,

\footnotetext{
${ }^{30}$ In Richard C. Martin, Approaches to Islam, 29.
}

${ }^{31}$ For example Kristina Nelson, The Art of Reciting the Qur'an (Austin: University of Texas Press, 1985); Said al-Labib, The Recited Qur'an, trans. Bernard Weiss et al. (Princeton: The Darwin Press, 1975); Frederick M. Denny, "Exegesis and Recitation: Their Development as Classical Forms of Qur'anic Piety," in Transitions and Transformations in the History of Religions, eds. Frank E. Reynolds and Theodore M. Ludwig (Leiden: E. J. Brill, 1980), 91-123; "The Adab of Qur'an Recitation: Text and Context," in International Congress for the Study of the Qur'an, ed. A. H. Johns (Canberra: Australian National University, 1980), 143-160.

${ }^{32}$ Journal of the American Academy of Religion, Thematic Studies 47, no. 45 (December 1979).

${ }^{33}$ For a detailed discussion, see Andrew Rippin "The Present Status of Tafsir Studies," Muslim World 72, nos. 3-4 (July-October 1982): 224-238. The state of the art in tafsir studies is represented in the published proceedings of a 1985 tafsir conference held at the University of Calgary: Andrew Rippin, ed., Approaches to the History of the Interpretation of the Qur'an (Oxford: Oxford University Press, 1988). 
1992) provides access in English to basic trends in this field. Thematic or terminological approaches to exegetical literature represent another trend relevant to the history of religions methodology.$^{34}$ It seems likely that once the broad outlines of this field become clearer, analytic and literary approaches both for hermeneutic and historical purposes will play a more significant role. Translations of major tafsir works by single authors will provide an increased sense of this discipline. The first volume of al Tabarī's tafsir is now available in English (1987), ${ }^{35}$ and al Tabataba'i's twenty-volume al Mizān is being translated by a team of scholars.

The figure of the Prophet, from a history of religions perspective, has received some recent attention, most notably in Annemarie Schimmel's study ${ }^{36}$ of the readings of the Prophet's sacred biography down through the centuries and across religious orientations among Muslims. Earle $\mathbf{H}$. Waugh has also explored the paradigmatic nature of the understanding of the Prophet in Sufi and popular piety. ${ }^{37}$ A noteworthy contribution to our understanding of the development of early sirah literature is Gordon Newby's The Making of the Last Prophet: A Reconstruction of the Earliest Biography of Muhammad (1989).

Studies of the hadith literature have been somewhat neglected as a field for theoretical research save for William A. Graham's Divine Word and Prophetic Word in Early Islam (1977). He considers the hadith qudsi (divine sayings) as a means to understanding the formation of divine and prophetic authority concepts in the early period of Islam. Muhammad Muhsin Khan has provided a nine-volume English translation of Sahih al Bukhäri (1979), and other Muslim scholars have published studies of traditional hadith methodology. While thematic approaches to hadith have focused on such topics as their portrayal of

${ }^{34}$ For example, Mahmoud Ayoub's articles "Towards an Islamic Christology," parts 1 \& 2, Muslim World 46, no. 3(1976): 163-88 and 80 (1980): 91-121; Jane McAuliffe's articles such as "Persian Exegetical Evaluation of the Ahl al-Kitab," Muslim World 73, no. 2 (April 1983): 87-105 and her recent Qur'anic Christians: An Analysis of Classical and Modern Exegesis (Cambridge: Cambridge University Press, 1991); also Jane I. Smith, An Historical and Semantic Study of the Term 'Islam' as Seen in a Sequence of Quran Commentaries (Missoula: Scholars Press, 1975).

${ }^{35}$ As is the translation of al Tabarī's thirty-eight volume world history (Albany: SUNY: 1984) undertaken by a team of prominent scholars, each of whom is responsible for one volume.

\footnotetext{
${ }^{36}$ Annemarie Schimmel, And Muhammad is His Messenger: The Veneration of the Prophet in Islamic Piety (Chapel Hill: University of North Carolina Press, 1985).

${ }^{37}$ Earle H. Waugh, "Following the Beloved: Muhammad as Model in the Sufi Tradition," in The Biographical Process, ed. D. Capps and Frank Reynolds (The Hague: Mouton 1976), 63-85, and Richard C. Martin, ed., "The Popular Muhammad," in Approaches to Islam in the History of Religions (Tempe: University of Arizona Press, 1985), 41-61.
} 
women, ${ }^{38}$ the chronology and authority of hadith has been carefully considered by G. H. A. Juynboll in Muslim Tradition (1983). Review articles on some aspects of hadith studies may be found in Arabic Literature to the End of the Umayyad Period (1983).

Since studies of Islamic jurisprudence, even if restricted to the Shari'ah, cover a number of technical approaches, I prefer to leave a comprehensive review of this field to a specialist. Significant trends from the standpoint of one primarily interested in the religious implications of law are the emergence of Islamic ethics as a field within the study of the Shari'ah as well as in other areas of Islamic thought. The problem of ethnocentric bias in understanding the relationship between law and the sacred is being reconsidered by Kevin Reinhart, for example, in his questioning of Schacht's exclusion of "the 'ibadat or acts directed to the divine power from the properly legal. ${ }^{139}$ Most recently, the issue of religious liberty from the comparative perspectives of the Western and Islamic traditions has been explored by David Little (the West), and John Kelsay and Abdulaziz Sachedina (Islam) in Human Rights and the Conflict of Cultures (1988). Contemporary political and social elements of the question of human rights in a number of Muslim societies are covered in Kevin Dwyer's Arab Voices: The Human Rights Debate in the Middle East (1991).

A volume of papers on Ethics in Islam (1985), based on the theme of the 1983 Giorgio Della Vida Conference, is just one indication of the attention being given to this field. Another one is that part of an issue of The Journal of Religious Ethics (Fall 1983) was devoted to Islamic ethics. While independent monographs and articles treating the ethical thought of such figures as Ibn Taymiyah and al Ghazzāli were produced, ${ }^{40}$ George Hourani's collected papers on Reason and Tradition in Islamic Ethics (1985) made available detailed studies on a number of themes from the standpoint of philosophical ethics.

For a critical survey of scholarship in Islamic philosophy, one can refer to Charles E. Butterworth's "The State of Arabic Philosophy Today" in Middle East Studies Association Bulletin 17, nos. 1 and 2 (1983). A general trend in this field is to show the interpenetration of philosophy with theological and mystical thought in Islam, several examples of which are the two volumes edited by Parviz Morewedge, Islamic Philosophical

\footnotetext{
${ }^{38}$ For example, Adele K. Ferdows and Amin H. Ferdows, "Women in Shi'i Fiqh: Images through the Hadith," in Women and Revolution in Iran, ed. Guity Nashat (Boulder: Westview, 1983): 55-68.

${ }^{39}$ A. Kevin Reinhart, "Islamic Law as Islamic Ethics," Journal of Religious Ethics 11 (Fall 1983): 186-203, and "Impurity No Danger: Islamic Purification Rituals and Scriptural Purity Rules," History of Religion 30 (August 1990): 1-24.

${ }^{40}$ Victor Makari, Ibn Taimiyya's Ethics (Scholars Press, 1983); M. A. Sharif, Ghazzali's Theory of Virtue (Albany: SUNY Press, 1975); and M. Abul Quassem, The Ethics of Al-Ghazzali (Quassem: 1975) .
} 
Theology (1979) and Islamic Philosophy and Mysticism (1981), as well as the collection of articles edited by Michael E. Marmura in Islamic Theology and Philosophy in Honor of George F. Hourani (1984).

Studies of Islamic theology have also been advanced through a continuation of detailed textual, analytical studies, particularly of the early sources. Among the more interesting are William Ormsby's Islamic Theodicity (1984), Aziz al-Azmeh's Arabic Thought and Islamic Societies (1986), and Michael Cook's Early Muslim Dogma (1981). Al-Azmeh and Ormsby break new ground in considering the underlying concerns of the mutakallimūn and their links to other spheres of Islamic intellectual life. Al-Azmeh's wide-ranging work applies the new methods of deconstruction and considers discursive formations across the various intellectual currents of medieval Islamic thought. His suggestion that an anthropological attitude of discovering the "indigenous" conceptual structure of medieval Arabic thought so that, for example, matters considered marginal today (i.e., alchemy) could be seen as reflecting central concerns, is consistent with the overall trends pointed out elsewhere in this review. ${ }^{41}$ A recent work using a semiotic approach, which suggests the emergence of a semiotic school of interpretation in Islamic studies at the University of Exeter, is Ian R. Netton's Allah Transcendent: Studies in the Structure and Semiotics of Islamic Philosophy, Theology, and Cosmology (1989).

At present, there is a movement towards understanding the conceptual underpinnings of the relationship between philosophy, theology, and usül al fiqh (the theory of jurisprudence). This will require an analysis of indigenous Islamic theories of language and signification, as has been undertaken in articles by Bernard Weiss. ${ }^{42}$ Weiss has recently produced an in-depth study of al 'Ämidī entitled The Search for God's Law (1992), which should serve as a benchmark for further translations and studies of ușül al figh. This would also require further basic studies on the thought of the "wisdom period"43 of later Islamic thought when the synthesis of theology, philosophy, and mystical thought was most fully articulated.

While specific theological texts have not yet been subjected to detailed analysis by the new methods of language and discourse analysis, we look forward to the publication of pioneering work by Richard C.

${ }^{41}$ For a discussion of these themes in al-Azmeh, see his Arabic Thought and Islamic Societies (London: Croom Helm, 1986), preface i-ix. Pertinent reflections on the need for cross-disciplinary approaches to Islamic thought can also be found in Mohammed Arkoun, Pour une critique de la raison islamique (Paris: Maisonneuve et Larose, 1984), 7-40.

\footnotetext{
${ }^{42}$ For example, Bernard Weiss, "Language and Tradition in Medieval Islam," Der Islam 61 (1984): 91-9.

${ }^{43}$ I have taken the term "wisdom period" from Muhsin Mahdi's article "Islamic Theology and Philosophy," Encyclopedia Britannica, vol. 9 (Chicago: Bunton, 1983), 1022. See S. H. Nasr, ed. "Theology, Philosophy, and Spirituality," Islamic Spirituality II (New York: Crossroads, 1991), 437-8, note no. 18 (p. 441) for brief notes and desiderata for the study of the later period.
} 
Martin along this line on early Mu'tazili texts. Representative of the new strategies for tracing underlying implications of the discursive formulations of writing and reasoning is the work being done on legal texts and contexts by Brinkley Messick. ${ }^{44}$

Studies on Sufi texts have received surprisingly little attention from the new cross-disciplinary methodologies, although very significant historical and translation work goes on in this field. Annemarie Schimmel's Mystical Dimension of Islam (1975) became on publication the classical compendium of historical and literary work in the field. While anthropologists and historians were interested in the Sufis' political and social activities, scholars of Islam focused recently on studies of individual Sufis and their writings, particularly by contributing important translations of works in the classical tradition.

The Paulist Press series on Classics of Western Spirituality published Ibn 'Arabi’s Bezels of Wisdom (trans. R. W. H. Austin, 1980), Khwaja Abdullah Ansari's Intimate Conversations (trans. Wheeler Thackston) together with Ibn 'Atā' Allāh's Book of Wisdom (trans. Victor Danner, 1978), Sharafuddin Maneri's The Hundred Letters (trans. Paul Jackson 1980), and Nizamaddin Auliya's Morals for the Heart (trans. Bruce Lawrence 1992). Hamid Algar's translation of Najmuddin Razi's The Path of God's Bondsmen from Origin to Return (1982) is also a noteworthy contribution. William Chittick continues to provide thematic and analytic translations of major Sufis with his Sufi Path of Love: The Spiritual Teachings of Rumi (1983), The Sufi Path of Knowledge: Ibn Arabi's Metaphysics of Imagination (1989), and his recent Faith and Practice of Islam: Three Thirteenth Century Sufi Texts (1992).

Literary and phenomenological approaches to Sufi texts will likely assume more importance in the future. A trend in this direction is evidenced by Gerhard Bowering's hermeneutic work on al Tustārī's mystical Qur'anic exegesis, The Mystical Vision of Existence in Classical Islam (1980), and Carl Ernst's Words of Ecstasy in Sufism (1985), which in part focuses on Sufi ecstatic utterances (shațhiyāt) as a genre. Michael Sells' articles on Ibn 'Arabī employ sophisticated literary analysis to illuminate his mystical thought through its modalities of expression. ${ }^{45}$

Future trends in Sufi studies will likely include further development of methods for interpreting mystical expression and its relationship to

44"The Mufti, the Text and the World: Legal Interpretation in Yemen," 21 Man. n.s. 102-19; "Kissing Hands and Knees: Hegemony and Hierarchy in Shari"ah Discourse," Law and Society 22 no. 4 (1988): 637-60. Messick's monograph, The Calligraphic State: Textual Domination and History and Domination in a Muslim Society (Berkeley: University of California Press, 1993) has recently become available.

${ }^{45}$ For example, see Sells" articles: "Ibn Arabi's Garden Among the Flames: A Reevaluation," History of Religion 23 (May 1984): 287-315; "Ibn al-Arabi's Polished Mirror" Studia Islamica 67 (1988): 121-49; and his "Bewildered Tongue: The Semantics of Mystical Union in Islam," in Mystical Union and Monotheistic Faith, ed. Bernard McGinn and Moshe Idel (New York: MacMillan, 1989), 87-124. 
Qur'anic language and more precise formulations of the role of Sufism within the larger context of Islam. For example, is there such a thing as neo-Sufism beginning in the eighteenth century; ${ }^{46}$ generally speaking, how "orthodox" was Sufism; and what is the relationship between the role of the Sufi and the "älim (learned scholar)? Barbara Daly Metcalf in her study of Islamic Revival in British India: Deoband 1860-1900 (1985) has provided insights into such shared roles based on historical and biographical material for the Indian context, and it would be interesting to see these roles studied in earlier periods and other environments.

The impact of "history of religions" training, which offers as one approach the study of particular forms or themes within a tradition, is seen in a number of recent studies. Examples are Mahmoud Ayoub's Redemptive Suffering in Islam (1978), Abdulaziz Sachedina's Islamic Messianism (1981), Peter Awn's Satan's Tragedy and Redemption: Iblis in Sufi Psychology (1983), and Yvonne Y. Haddad's Contemporary Islam and the Challenge of History (1982).

An explosion of interest in Shi'a studies over the past ten years must be noted both from the history of religions and from cultural and political studies perspectives. While Abdulaziz Sachedina and Mahmoud Ayoub contributed the above-mentioned thematic studies as well as relevant articles, new surveys by S. Husain M. Jafri (1979), Tabataba'i, and, recently, by Momen became available for the first time during this period. ${ }^{47}$ Political and cultural studies too numerous to mention greatly expanded knowledge of the Shi'a tradition in contemporary Iran, particularly in the wake of the revolution. Translations of the works of "Ali Shariati and Ayatollahs Khomeini and Motahhari were made more readily available than any similar body of contemporary material within the Sunni tradition. While previous scholarship on Shi'ism focused on its esoteric, mystical, and philosophical orientations, ${ }^{48}$ we now have a wealth of material on political theory, institutions, popular piety, and contemporary movements. A growing trend in studies on Shi ism will bring to scholarly attention new material on Shi'a sectarianism, ${ }^{49}$ Shi 'ism in local non-

${ }^{46} \mathrm{~A}$ recent review of this debate may be found in R. S. O'Fahey, Enigmatic Saint: Ahmad ibn Idris and the Idrisi Tradition (Evanston: Northwestern University Press, 1990), $1-9$.

${ }^{47}$ Moojan Momen, An Introduction to Shi 'i Islam: The History and Doctrines of Twelver Shi 'ism (Yale: 1985); Syed H. Jafri, Origins and Early Development in Shi'a Islam (New York: Longman, 1979); Muhammad Tabataba'i, Shi'ite Islam, trans. S. H. Nasr (New York: Longman, 1979).

\footnotetext{
${ }^{48}$ For example, the scholarship of Henry Corbin reviewed by Charles J. Adams, "The Hermeneutics of Henry Corbin," in Approaches to Islam, ed. R. C. Martin, 129-50.

${ }^{49}$ Such as Matti Moosa, Extremist Shi'ites: The Ghulat Sect (Syracuse: Syracuse University Press, 1988); Azim Nanji, The Nizari Ismailis in the Indo-Pakistan Sub-continent (Delmar, NY: Caravan, 1978); and Farhad Daftary, The Isma'ilis: Their History and Development (Cambridge: Cambridge University Press, 1990). Careful scholarship (cont.)
} 
Iranian contexts, ${ }^{50}$ and further detailed studies of the classical Shi ${ }^{\circ}$ a tradition in law and theology. ${ }^{51}$

The political developments that make Islam so prominent in current public awareness are also reflected in an increasing number of scholarly publications investigating the apparent resurgence, revival, and political expression of the tradition in human action. While in some cases the approach to the phenomena's Islamic or religious dimension is superficial, a number of scholars have made valuable contributions to understanding the religious meanings of more recent movements and developments. While a detailed review of works with a more political focus is beyond the scope of the current paper, an approach that addresses the concerns of scholars with a history of religions focus is most aptly represented by Bruce Lawrence's Defenders of God (1990), a study in "fundamentalism" as a response to modernity seen across the three Western religions and John L. Esposito's The Islamic Threat: Myth or Reality (1992).

As Islamic studies has come to occupy a position in the undergraduate curriculum, the need for educational materials has produced new contributions. The new recognition accorded to aspects of personalist and little tradition Islam is evident in the first textbook on Islam written primarily from a history of religions perspective and which, in addition, takes ritual and practice seriously into account. This is Frederick M. Denny's Introduction to Islam (1985). The slide set on Islamic ritual practices, prepared by Denny and Sachedina, confirms the trend to acknowledge "individual practice or lived Islam" as an object of study. Its inclusion of slides showing Muslim activities in mosques and homes in the United States, Makkah, Cairo, and Indonesia is yet another indication of the current's recognition of the presence of Islam in many different cultural contexts.

Also of interest is the trend within Muslim scholarship to recover, delineate, and ultimately institute the authentically Islamic. The main groups sharing in this endeavor include scholars of a traditionalist, sympathetic

(cont.) on Shi`a and Ismā‘īlì doctrinal development was made available in Wilferd Madelung's collected articles: Reli-gious Schools and Sects in Medieval Islam (London: Variorem Reprints, 1985).

${ }^{50}$ For example, Juan Cole's Imami Shi'ism from Iran to North India 1722-1856: State, Society, and Clerical Ideology in Awadh (Berkeley: University of California Press, 1984) and Brinkley Messick's Calligraphic State, which concerns Zaidi Shi'ism in Yemen.

${ }^{51}$ For example, Sachedina's The Just Ruler in Shi'ite Islam: The Comprehensive Authority of the Jurist in Imamite Jurisprudence (Oxford: Oxford University Press, 1988) and the works of Said Amir Arjomand, incleling Authority and Political Culture in Shi'ism (New York: SUNY Press, 1988); The Shadow of God and the Hidden Imam (Chicago: University of Chicago Press, 1984); and The Turban for the Crown: The Islamic Revolution in Iran (Oxford: Oxford University Press, 1988). See also Juan Cole and Nikki Keddie, eds., Shi'ism and Social Protest (Syracuse: Syracuse University Press, 1989); and Hamid Dabashi's three recent volumes: Shi 'ism: Doctrine, Thought. and Spirituality (New York: SUNY, 1988); Expectations of the Millennium: Shi'ism in History (New York: SUNY, 1989); and Authority in Islam (New Brunswick, NJ: Transaction, 1989). 
to Sufism persuasion such as Seyyed Hossein Nasr, ${ }^{52}$ Naguib al-Attas, and Sayyid Ali Ashraf ${ }^{53}$; a more technocratic scientific faction; ${ }^{54}$ and those associated with conservative positions such as the late I. R. al Fārūqi.$^{55}$ These currents in contemporary Muslim thought in the West have generally not received a great deal of scholarly attention in the United States. While chapters on the thought of al Färūqī, Rahman, and Nasr in Haddad's (ed.) Muslims of America (1991) are notable exceptions, discussions by Akbar Ahmad in his Postmodernism and Islam (1992) indicate the liveliness of the academic-literary Muslim intellectual scene in Great Britain.

In conclusion, I would like to summarize and restate a number of themes in the current state of Islamic studies that have emerged within this review.

One observation is the difficulty, particularly within Islamic studies, of defining in the field a body of scholarship confined to specifically "religious" themes. This is partly due to the unique comprehensiveness of the Islamic tradition. It also results from the explosion of the myth, within the last decade, that textual studies in isolation permit the study of "purely religious themes." This occurs with new attitudes to textuality and the shaping power of forces outside of the text on its construction and expression.

Overall, the focus on "Islam" within the field, if not shifting to "Muslim," has at least widened to consider that aspect of the tradition. Taking the "Muslim" into account means:

a) More interest in historical change, not only in the transmission of knowledge through institutions and authoritative discourse, but in the use and definition of normative concepts with the tradition itself;

b) more attention to "lived" Islam in terms of practice, texts in context

${ }^{52} \mathrm{~A}$ review of Nasr's numerous publications which reflect a traditionalist-perennialist perspective is beyond the scope of the present review. Recent examples are his two edited volumes on Islamic Spirituality in the Crossroads Press series on World Spirituality. The purpose of this series is to acquaint a general and scholarly audience with "authentic" spirituality in the world's religious traditions. Nasr and his contributions define this primarily in terms of Sufism and its intellectual and cultural manifestations.

${ }^{53}$ As evident in much of Nasr's work and in the volumes of the Islamic Education Series (Jeddah, 1979), including papers by al-Attas and S. A. Ashraf, and the journal Muslim Education Quarterly.

${ }^{54}$ For example, the writings of Ziauddin Sardar and others who were involved in the now defunct Afkar Inquiry magazine.

${ }^{55} \mathrm{Al}$ Fārūqi and his followers constitute another branch of the "Islamization of Knowledge Movement," which would include the International Institute of Islamic Thought. See, for example, his pamphlet Islamization of Knowledge (Herndon, VA: International Institute of Islamic Thought, 1982.) 
(i.e., studies of the recited Qur'an), local environments, ${ }^{56}$ and selfstatements, which brings scholars of Islam into greater interaction with the social sciences;

c) the expansion of methodology to incorporate eclectic, multidisciplinary approaches to textual analysis as part of a movement across all of the humanities disciplines; and

d) a more sophisticated and nuanced approach to studies of Islam and gendering which, in turn, will influence how religion and especially women's roles in Islamic tradition are taught and studied in the academy. Feminist rereadings of religious, literary, and historical texts by Fatima Mernissi, Fedwa Malti-Douglas, and Leila Ahmed are one reflection of this trend. ${ }^{57}$ As well as being an area attracting broad public and academic interest from outside the discipline, this topic represents the cutting edge of the intersection of insights derived from contemporary literature and literary theory with the study of Islam.

Therefore, we may expect a continuing but slow expansion as the study of Islam is included in more undergraduate religion programs. A positive trend is that more scholars of Islam with an interest in the history of religions are organizing within the American Academy of Religion, the American Oriental Society, Council for the Study of Islamic Societies, and other thematic gatherings. Within studies of the Islamic religious tradition and area studies, tension between the social science emphasis on explanation and the descriptive focus of philological and cultural studies is being mediated by shared interests in multidisciplinary approaches to interpretation.

\section{References}

Ahmed, Akbar S. Postmodernism and Islam. London: Routledge, 1992. al-Azmeh, Aziz. Arabic Thought and Islamic Societies. London: Croom Helm, 1986.

Ansari, Khwaja Abdullah. Intimate Conversations. Translated by Wheeler Thackston, together with Ibn 'Ațā' Allāh's The Book of Wisdom.

Translated by Victor Danner. New York: Paulist Press, 1978. Awn, Peter. Satan's Tragedy and Redemption: Iblis in Sufi Psychology.

Leiden: Brill, 1983.

${ }^{56}$ For example, Juan R. Campo, The Other Sides of Paradise: Explorations in the Religious Meaning of Domestic Space in Islam (Columbia: University of South Carolina Press, 1991).

${ }^{57}$ Fatima Mernissi, Women and Islam: An Historical and Theological Survey (Oxford: Blackwell, 1991); Fedwa Malti-Douglas, Woman's Body, Woman's Word: Gender and Discourse in Arabo-lslamic Writing (Princeton: Princeton University Press, 1991); Leila Ahmed, Women and Gender in Islam (New Haven: Yale University Press, 1992). 
Ayoub, Mahmoud. Redemptive Suffering in Islam. The Hague: Mouton, 1978.

The Qur'an and Its Interpreters, vols. I \& II. Albany: State University of New York, 1984, 1992.

Beeston, A. F. L. et al. Arabic Literature to the End of the Umayyad

Period. Cambridge: Cambridge University Press, 1983.

Bowering, Gerhard. The Mystical Vision of Existence in Classical Islam.

Berlin: DeGruyter, 1980.

al Bukhārī. Sahih al Bukhārī. Translated by Muhammad Muhsin Khan.

9 volumes. Lahore: Kazi, 1979.

Bulliet, Richard C. The Patricians of Nishapur. Cambridge, MA: Harvard University Press, 1972.

----. Conversion to Islam in the Medieval Period. Cambridge, MA: Harvard University Press, 1979.

Butterworth, Charles E. "The State of Arabic Philosophy Today." Middle East Studies Association Bulletin 17, no. 1, (1983): 8-24; no. 2, (1983): 161-177.

Chittick, William. The Sufi Path of Love: The Spiritual Teachings of Rumi. Albany: SUNY Press, 1983.

----. The Sufi Path of Knowledge: Ibn Arabi's Metaphysics of Imagination. Albany: SUNY Press, 1989.

----. Faith and Practice of Islam: Three Thirteenth Century Sufi Texts. Albany: SUNY Press, 1992.

Cook, Michael. Early Muslim Dogma. Cambridge: Cambridge University Press, 1981.

Cook, Michael and Patricia Crone. Hagarism. Cambridge: Cambridge University Press, 1977.

Denny, Fred M. An Introduction to Islam. New York: Macmillan, 1985. Denny, Fred M. and Abdulaziz Sachedina. Islamic Ritual Practices: A Slide Set and Teacher's Guide. New York: American Council of Learned Societies, 1983.

Dwyer, Kevin. Arab Voices: The Human Rights Debate in the Middle East. Berkeley: University of California Press, 1991.

Eaton, Richard. Sufis of Bijapur. Princeton: Princeton University Press, 1978.

Eccles, Chris. Egypt, Islam and Social Change. Berlin: K. Schwarz, 1983. Ernst, Carl. Words of Ecstasy in Sufism. Albany: SUNY, 1985.

Esposito, John. Voices of Resurgent Islam. New York: Oxford University Press, 1983.

----. The Islamic Threat: Myth or Reality. Oxford: Oxford University Press, 1992.

Esposito, John L. and John J. Donahue. Islam in Transition: Muslim Perspectives. New York: Oxford University Press, 1982.

Ewing, Katherine P. Shariat and Ambiguity in South Asian Islam. Berkeley: University of California Press, 1988.

Fischer, Michael. Iran from Religious Dispute to Revolution. Cambridge, MA: Harvard University Press, 1980. 
Fischer, Michael and Mehdi Abedi. Debating Muslims. Madison: University of Wisconsin, 1990.

Gatje, Helmut. The Qur'an and its Exegesis. Translated by A. T. Welch. Berkeley: University of California Press, 1976.

Geertz, Clifford. Islam Observed: Religious Developments in Morocco and Indonesia. New Haven: Yale, 1968.

Gellner, Ernest. Postmodernism, Reason, and Religion. London: Routledge, 1992.

Graham, William. Divine Word and Prophetic Word in Early Islam. The Hague: Mouton, 1977.

-----. Beyond the Written Word: Oral Aspects of Scripture in the History of Religions. Cambridge: Cambridge University Press, 1987.

Haddad, Yvonne Y. Contemporary Islam and the Challenge of History. Albany: SUNY, 1982.

-----, ed. Muslims of America. Oxford: Oxford University Press, 1991.

Hodgson, Marshall S. The Venture of Islam. Chicago: University of Chicago, 1974.

Hourani, George. Reason and Tradition in Islamic Ethics. Cambridge: Cambridge University Press, 1985.

Hovannisian, Richard G. Ethics in Islam. 9th Giorgio Della Vida Conference. Malibu, CA: Undena, 1985 .

Ibn Arabi. Bezels of Wisdom. Translated by R. W. H. Austin. New York: Paulist Press, 1980.

Juynboll, G. H. A. Muslim Tradition. Cambridge: Cambridge University Press, 1983.

Kassis, Hanna. Concordance to the Qur'an. Berkeley: University of California Press, 1983.

Lawrence, Bruce. Defenders of God. New York: MacMillan, 1990.

Lelyveld, David. Aligarh's First Generation. Princeton: Princeton University Press, 1978.

Little, David, John Kelsay and Abdulaziz Sachedina. Human Rights and the Conflict of Cultures. Columbia: University of South Carolina Press, 1988.

Maneri, Sharafuddin. The Hundred Letters. Translated by Paul Jackson. New York: Paulist Press, 1980.

Marmura, Michael E. Islamic Theology and Philosophy in Honor of George F. Hourani. Albany, NY: SUNY Press, 1984.

Martin, Richard C. Approaches to Islam in Religious Studies. Tempe: University of Arizona, 1985.

Metcalf, Barbara Daly. Islamic Revival in British India Deoband: 18601900. Princeton: Princeton University Press, 1985.

-----. ed. Moral Conduct and Authority: The Place of Adab in South Asian Islam. Berkeley: University of California Press, 1984.

Morewedge, Parviz. Islamic Philosophical Theology. Albany: SUNY Press, 1979.

. Islamic Philosophy and Mysticism. Delmar, NY: Caravan Books, 1981. 
Mottahedeh, Roy. The Mantle of the Prophet: Religions and Politics in Iran. New York: Simon and Schuster, 1985.

Netton, Ian R. Allah Transcendent: Studies in the Structure and Semiotics of Islamic Philosophy, Theology, and Cosmology. London: Routledge, 1989.

Newby, Gordon. The Making of the Last Prophet: A Reconstruction of the Earliest Biography of Muhammad. Columbia: University of South Carolina, 1989.

Nizamaddin Auliya. Morals for the Heart. Translated by Bruce Lawrence. New York: Paulist Press, 1992.

Ormsby, William. Islamic Theodicity. Princeton: Princeton University Press, 1984.

Petry, Carl. The Civilian Elite of Cairo in the Later Middle Ages. Princeton: Princeton University Press, 1981.

Rahman, Fazlur. Major Themes of the Qur'an. Minneapolis: Bibliotheca Islamica, 1980.

Islam and Modernity: The Transformation of an Intellectual Tradition. Chicago: University of Chicago Press, 1982.

Razi, Najmuddin. The Path of God's Bondsmen from Origin to Return. Translated by Hamid Algar. Delmar, NY: Caravan, 1982.

Sabbah, Fatna. Women in the Muslim Unconscious. New York: Pergamon, 1984.

Sachedina, Abdulaziz. Islamic Messianism. Albany: SUNY, 1981.

Said, Edward. Orientalism. New York: Pantheon, 1978.

Schimmel, Annemarie. Mystical Dimension of Islam. Chapel Hill: University of North Carolina Press, 1975.

Smith, Jane I. and Yvonne Y. Haddad. Islamic Understanding of Death and Resurrection. Albany: SUNY Press, 1981.

al Tabarī. The Commentary of the Qur'an, vol. 1. Translated by J. Cooper. Oxford: Oxford University Press, 1987.

Wansbrough, John. Quranic Studies. Oxford: Oxford University Press, 1977.

Weiss, Bernard. The Search for God's Law: Islamic Jurisprudence in the Writings of Sayf al-Din al-Amidi. Salt Lake City, Utah: University of Utah, 1992.

Marcia K. Hermansen Department of Religious Studies San Diego State University San Diego, California 